\title{
ACE polymorphisms and COVID-19-related mortality in Europe
}

\author{
Matteo Bellone ${ }^{1}$ (D) $\cdot$ Stefania Laura Calvisi ${ }^{1}$ \\ Received: 15 July 2020 / Revised: 2 September 2020 / Accepted: 11 September 2020 / Published online: 15 September 2020 \\ (C) Springer-Verlag GmbH Germany, part of Springer Nature 2020
}

The severe acute respiratory syndrome coronavirus 2 (SARSCoV-2) has emerged in China at the end of 2019 and has rapidly spread to Asia, Oceania, Europe, and America causing the coronavirus disease-19 (COVID-19) pandemic [1] and more than 700,000 deaths worldwide as of August 6, 2020. Epidemiology analyses have been showing higher mortality due to COVID-19 in Europe than in China [2]. In Table 1, we report the number of fatalities due to COVID-19 both in relation to the number of total cases (i.e., mortality) and the entire population of the indicated country (i.e., death/1 million population) as of August 5, 2020. The two parameters are differently influenced by several variables (e.g., the number and type of tests each country has used to confirm the clinical diagnosis, the access to hospitalization, or the parameters used to ascribe death to COVID-19). Considering that the mortality parameter strictly depends on the number of test performed in each country, and that testing has neither been homogeneously performed in the different countries [3] nor the entire populations of these countries have been screened, we focused on the death/1 million population. As reported in Table 1, COVID19-related deaths are much less in China than in Europe. Furthermore, deaths related to COVID-19 are not equally distributed in Europe. Northern European countries, for example, Denmark, Germany, and Norway, have experienced rates of COVID-19-related deaths closer to China than Southern European countries like Italy, Spain, or France. There are several exceptions to this apparent rule. For example, the Belgian National Health Institute has been counting even suspected cases of COVID-19-related deaths, regardless of whether the deceased person was tested. Northern European countries like the UK and Sweden did not impose a lockdown, thus diverging from the politics of social containment to face the pandemic

The work has not been previously presented.

Matteo Bellone

bellone.matteo@hsr.it

1 I.R.C.C.S. Ospedale San Raffaele, Via Olgettina 60, 20132 Milan, Italy adopted by several other European nations. These considerations may apply to other countries worldwide.

Median age of the population (Table 1), social behaviors that are more distinctive of Southern European countries (e.g., intense social life in crowded places, warm greetings, apartments shared by youngsters and elders), or even air pollution [4-6] are additional factors that have been implicated in COVID-19-related mortality. As for the European countries analyzed in Table 1, median age of inhabitants does not appear to have a relevant impact on COVID-19-related mortality (Fig. 1a).

The renin-angiotensin-aldosterone system (RAAS) is under scrutiny in the coronavirus COVID-19 pandemic [7] because the angiotensin-converting enzyme 2 (ACE2) is the main receptor for the SARS-CoV-2 on alveolar epithelial cells [8]. ACE2 and the serine protease TMPRSS2, which is necessary for spike protein priming, are also expressed in several other tissues, including blood vessels, olfactory epithelium, brain, heart, kidney, and intestine, thus explaining the multiorgan dysfunction observed in COVID-19 patients [9, 10].

Increased expression of ACE2 in elder males has been put forward to explain the increased SARS-CoV-2 aggressiveness in this subpopulation [9]. However, treatment with ACE inhibitors or angiotensin receptor blockers, which may also cause increased ACE2 expression, does not associate with more severe COVID-19 [11-15]. Additionally, ACE2 counterbalances deleterious vasoconstrictive, proinflammatory, and profibrotic effects of angiotensin (Ang) II by generating downstream peptides such as the hypotensive metabolite Ang1-7 [7]. Indeed, targeted disruption of ACE2 in mice causes severe cardiac contractility defects, increased Ang II levels, and upregulation of hypoxia-induced genes in the heart [16]. ACE2 also exerts a protective effect by limiting leukocyte accrual during acute respiratory distress syndrome in mice, and recombinant ACE2 can protect mice from lung injury [17]. Finally, it has been recently reported that soluble human ACE2 can inhibit SARS-Cov-2 infection in human blood vessel organoids and human kidney organoids [18]. Thus, the role of the RAAS in COVID-19 is far from being elucidated. 
Table 1 Summary of population median age, COVID-19*-related mortality, and ACE polymorphisms in the different countries under evaluation.

\begin{tabular}{|c|c|c|c|c|c|c|c|c|}
\hline \multirow[t]{2}{*}{ Nation } & \multirow{2}{*}{$\begin{array}{l}\text { Population } \\
\text { median } \\
\text { age** }\end{array}$} & \multirow{2}{*}{$\begin{array}{l}\text { Mortality, total } \\
\text { deaths/total cases } \\
(\%)^{* *}\end{array}$} & \multirow{2}{*}{$\begin{array}{l}\text { Death/1M } \\
\text { population** }\end{array}$} & \multicolumn{5}{|c|}{$A C E$ polymorphisms } \\
\hline & & & & $\mathrm{I} / \mathrm{I}$ & $\mathrm{I} / \mathrm{D}$ & $\mathrm{D} / \mathrm{D}$ & $\begin{array}{l}\text { Studied } \\
\text { population } \\
\text { age }\end{array}$ & Reference \\
\hline China & 38.4 & 5.58 & 3 & 0.39 & 0.43 & 0.18 & $<70$ & He Q et al. (2013) PLoS One 8: e75870 \\
\hline Austria & 43.5 & 3.34 & 80 & 0.21 & 0.50 & 0.29 & $<75$ & $\begin{array}{l}\text { Sunder-Plassmann G et al. (2002) Crit Care } \\
\text { Med 30: } 2236-2241\end{array}$ \\
\hline Belgium & 41.9 & 14.0 & 850 & 0.17 & 0.48 & 0.35 & $<83$ & $\begin{array}{l}\text { Tournoy KG et al. (1996) Clin Chim Acta 255: } \\
39-55\end{array}$ \\
\hline $\begin{array}{l}\text { Bosnia and } \\
\text { Herzegovina }\end{array}$ & 43.1 & 2.90 & 114 & 0.18 & 0.52 & 0.30 & $<55$ & $\begin{array}{l}\text { Klupka-Saric I et al. (2011) Genet Test Mol } \\
\text { Biomarkers 15: 835-838 }\end{array}$ \\
\hline Croatia & 44.3 & 2.89 & 38 & 0.28 & 0.50 & 0.22 & $<60$ & $\begin{array}{l}\text { Lovrecic L et al. (2006) Acta Neurol Scand } \\
\text { 114: 374-377 }\end{array}$ \\
\hline Czechia & 43.2 & 2.21 & 36 & 0.19 & 0.48 & 0.33 & $<55$ & $\begin{array}{l}\text { Hladikova M et al. (2011) J Neurol Sci 303: } \\
\text { 31-34 }\end{array}$ \\
\hline Denmark & 42.3 & 4.38 & 106 & 0.23 & 0.51 & 0.26 & $<55$ & $\begin{array}{l}\text { Panza F et al. (2003) Exp Gerontol 38: } \\
\text { 1015-1020 }\end{array}$ \\
\hline Finland & 43.1 & 7.33 & 60 & 0.24 & 0.49 & 0.27 & NR & $\begin{array}{l}\text { Pietinalho A et al. (1999) Eur Respir J 13: } \\
\text { 723-726 }\end{array}$ \\
\hline France & 42.3 & 15.84 & 464 & 0.18 & 0.46 & 0.36 & $<55$ & $\begin{array}{l}\text { Rigat B et al. (1990) J Clin Invest 86: } \\
\quad 1343-1346\end{array}$ \\
\hline Germany & 45.7 & 4.35 & 110 & 0.21 & 0.52 & 0.27 & $<90$ & $\begin{array}{l}\text { Hucl T et al. (2009) Eur J Gastroenterol } \\
\text { Hepatol 21: 1032-1035 }\end{array}$ \\
\hline Greece & 45.6 & 4.3 & 20 & 0.17 & 0.48 & 0.35 & $<80$ & $\begin{array}{l}\text { Karagiannis A et al. (2004) Eur Neurol 51: } \\
\quad 148-152\end{array}$ \\
\hline Hungary & 43.3 & 13.12 & 62 & 0.28 & 0.49 & 0.23 & $<80$ & Szolnoki Z et al. (2001) J Neurol 248: 756-761 \\
\hline Northern Ireland & 38.2 & 6.72 & 357 & 0.24 & 0.49 & 0.27 & $<65$ & $\begin{array}{l}\text { Kee F et al. (2000) Eur J Clin Invest 30: } \\
\text { 1076-1082 }\end{array}$ \\
\hline Italy & 47.3 & 14.17 & 582 & 0.13 & 0.47 & 0.40 & $<70$ & $\begin{array}{l}\text { Panza F et al. (2003) Exp Gerontol 38: } \\
\text { 1015-1020 }\end{array}$ \\
\hline Italy & & & & 0.12 & 0.42 & 0.46 & $\geq 100$ & $\begin{array}{l}\text { Panza F et al. (2003) Exp Gerontol 38: } \\
\text { 1015-1020 }\end{array}$ \\
\hline Lithuania & 45.1 & 3.74 & 29 & 0.26 & 0.46 & 0.28 & $<75$ & Kupcinskas J (2011) BMC Med Genet 12: 112 \\
\hline Montenegro & 39.8 & 1.58 & 84 & 0.19 & 0.53 & 0.28 & NR & $\begin{array}{l}\text { Kostic M et al. (2004) Pediatr Nephrol 19: } \\
853-857\end{array}$ \\
\hline Netherlands & 43.3 & 10.99 & 359 & 0.24 & 0.50 & 0.26 & $<65$ & $\begin{array}{l}\text { van der Sman-de Beer F et al. (2005) Kidney } \\
\text { Int 68: 2237-2243 }\end{array}$ \\
\hline Norway & 39.8 & 2.74 & 47 & 0.23 & 0.51 & 0.26 & $<70$ & Tronvik E, et al. (2008) BMC Neurol 8: 4 \\
\hline Poland & 41.7 & 3.59 & 46 & 0.35 & 0.43 & 0.22 & $<50$ & $\begin{array}{l}\text { Zak I et al. (2003) Acta Biochim Pol 50: } \\
\text { 527-534 }\end{array}$ \\
\hline Portugal & 46.2 & 3.36 & 171 & 0.17 & 0.47 & 0.36 & $<70$ & $\begin{array}{l}\text { Pereira da Silva A et al. (2019) Mol Cell } \\
\text { Biochem 455: 61-71 }\end{array}$ \\
\hline Russia & 39.6 & 1.67 & 99 & 0.25 & 0.46 & 0.29 & $<92$ & $\begin{array}{l}\text { Farrer LA et al. (2000) Arch Neurol 57: } \\
\text { 210-214 }\end{array}$ \\
\hline Serbia & 41.6 & 2.26 & 69 & 0.17 & 0.53 & 0.29 & $<65$ & $\begin{array}{l}\text { Zivkovic M et al. (2016) J Neurol Sci 363: } \\
\text { 29-32 }\end{array}$ \\
\hline Slovenia & 44.5 & 5.61 & 60 & 0.26 & 0.53 & 0.21 & $<59$ & $\begin{array}{l}\text { Salobir B et al. (2007) Med Sci Monit 13: } \\
\text { CR538-542 }\end{array}$ \\
\hline Spain & 44.9 & 8.14 & 609 & 0.14 & 0.51 & 0.35 & NR & $\begin{array}{l}\text { Martinez E et al. (2000) J Hum Hypertens 14: } \\
\text { 131-135 }\end{array}$ \\
\hline Sweden & 41.1 & 7.08 & 569 & 0.22 & 0.51 & 0.27 & $>18$ & $\begin{array}{l}\text { Kurland L et al. (2001) J Hypertens 19: } \\
\text { 1783-1787 }\end{array}$ \\
\hline United Kingdom & 40.5 & 15.12 & 682 & 0.24 & 0.50 & 0.26 & $<55$ & $\begin{array}{l}\text { Marshall RP et al. Am J Respir Crit Care Med } \\
\text { 166: 646-650 }\end{array}$ \\
\hline
\end{tabular}

*COVID-19 coronavirus disease $19, N R$ not reported, Ref reference, $1 M$ one million, $I$ insertion, $D$ deletion

*** Data source: https://www.worldometers.info/coronavirus/ updated to August 5, 2020. 

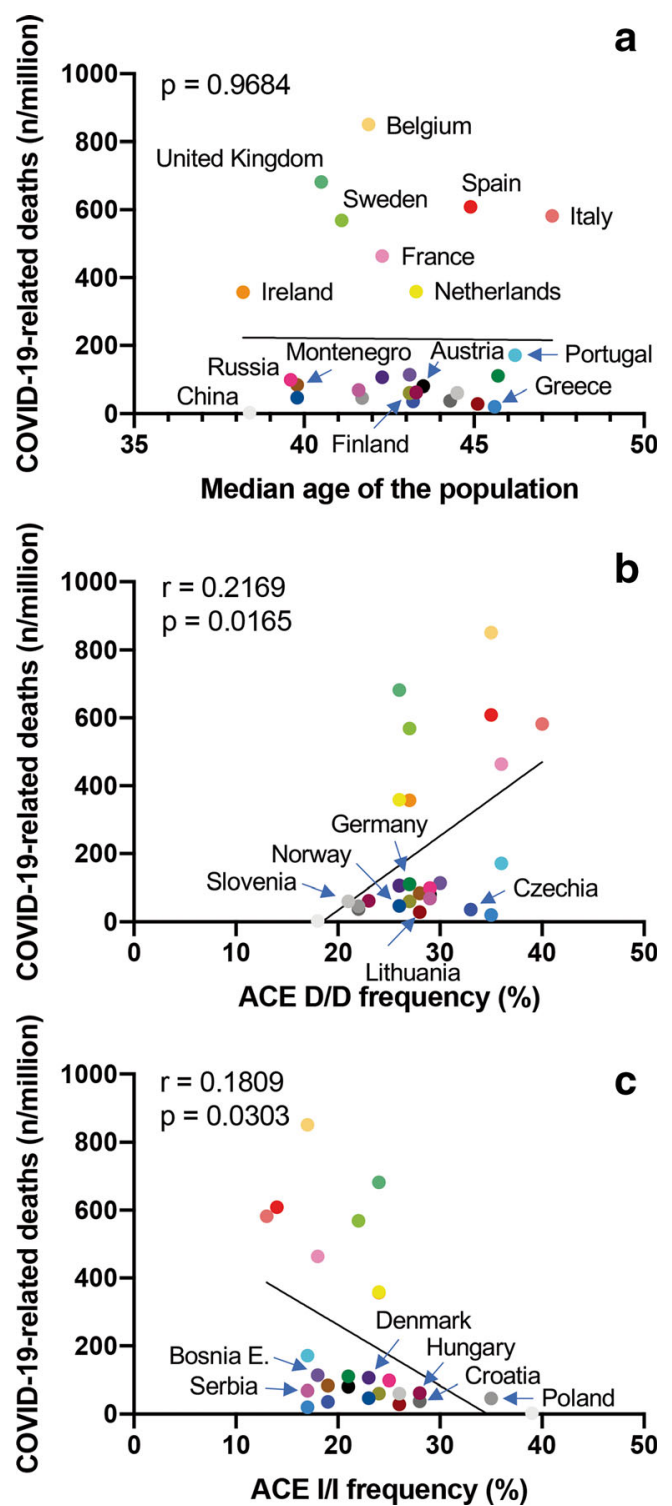

Fig. 1 Prevalence of COVID-19-related deaths (number of deaths $/ 10^{6}$ inhabitants) versus median age of the population of the specified country (a), ACE Del/Del polymorphisms expressed in percentage (b), and ACE Ins/Ins polymorphisms expressed in percentage $(\mathbf{c})$. Numbers in panels refer to $R$ squared $(r)$ and $p$ value $(p)$ for simple linear regression. Nations are reported in color code: Austria, black; Belgium, cantaloupe; Bosnia and Erzegovina, grape; China, mercury; Czechia, blueberry; Croatia, iron; Denmark, eggplant; Finland, asparagus; France, carnation; Germany, moss; Greece, aqua; Hungary, maroon; Ireland, tangerine; Italy, salmon; Lithuania, cayenne; Montenegro, mocha; Netherlands, lemon; Poland, nickel; Portugal, turquoise; Russia, strawberry; Serbia, magenta; Slovenia, magnesium; Spain, maraschino; Sweden, lime; UK, sea foam

ACE2 polymorphisms have been investigated with no evidence of an association with the aggressiveness of severe acute respiratory syndrome [19]. The $A C E$ gene contains an insertion/deletion (Ins/Del) polymorphism (rs4646994; ref. [20]), which associates with higher serum ACE levels [20], obesity [21], hypertension [22], increased cardiovascular risk [23], and thrombophilia [24]; all clinical conditions correlated with more aggressive COVID-19 [1]. Additionally, the $A C E$ $\mathrm{Del} / \mathrm{Del}$ polymorphism has been associated with mortality in acute respiratory distress syndrome (ARDS) [25]. Our hypothesis is that increased availability of ACE due to $A C E$ Del/Del polymorphism might help explain why SARS-CoV2 is hitting so hard in Southern Europe.

We found that the distribution of $A C E$ polymorphisms varied among populations, and Del/Del was much more represented in Italy, especially in the eldest, than in China. A gradient in Del/Del polymorphism was also apparent moving from the south to the north of Europe (Table 1). As reported in Fig. 1b, a simple linear regression showed an association between $\mathrm{Del} /$ Del polymorphism and COVID-19-related deaths in 25 European countries for which we were able to retrieve comparable information on $A C E$ polymorphisms (e.g., gender distribution, age, samples analyzed). Because data appeared bimodally distributed, they were also analyzed by Spearman's correlation. The association between $A C E$ Del/Del polymorphism and COVID-19-related deaths remained significant $(r$ $0.4024(95 \% 0.005720$ to 0.6896$), p($ two tailed $)=0.0416)$.

A potential association between $A C E$ polymorphisms and COVID-19 was already investigated by Delanghe and colleagues, who compared the Del-allele frequency of $A C E$ with the mortality of COVID-19 in 25 different European countries [26]. They found a significant correlation between COVID-19related deaths and the prevalence of the $A C E$ D-allele (Spearman $r=-0.510, p=0.01$ ). However, focusing on $\mathrm{D}$ allele, the authors aggregated Ins and Del polymorphisms in the analysis, thus diluting the negative effect of Del/Del into the positive effects of Ins/Ins polymorphisms. Indeed, in our analysis, Ins/Ins polymorphism inversely correlated with COVID-19-related deaths (Fig. 1c, Spearman: $r=-0.4898$ $(95 \%,-0.7427$ to -0.1145$), p($ two tailed $)=0.0111)$. $\mathrm{A}$ correlation between Ins/Del polymorphism and COVID-19related deaths was not found (Table $1 ; p=0.9061$ ). Altogether, these findings suggest a pathogenic role of ACE in COVID-19. This finding might also help explain why in Southern Europe COVID-19-associated mortality has been so high. ACE polymorphisms remain one of probably many genetic and non-genetic factors influencing COVID-19 outcomes.

Abundance of ACE in the blood of Del/Del COVID-19 patients might favor the generation of Ang II. Additionally, ACE2 receptor downregulation caused by SARS-Cov-2 engagement increases Ang II availability, and its deleterious effects downstream of the Ang II type 1 receptor [17]. ACE2 downregulation might also facilitate neutrophil recruitment in the lungs, eventually leading to increased tissue damage. Additionally, Ang II is involved in platelet activation and aggregation [27], which may occur in COVID-19 patients [1]. Dysregulation of RAAS due to excessive ACE might also explain the increased susceptibility of elders to COVID-19 [28], in which the Del/Del polymorphism is particularly high 
(Table 1). Thus, serum ACE levels and/or Del/Del polymorphism might be predictive of more aggressive disease.

Based on these premises, $A C E$ Del/Del polymorphism and serum ACE levels should be investigated as predictive biomarkers of COVID-19 aggressiveness, as it has been already proposed in ARDS patients [29], and ACE and Ang II might be potential therapeutic targets in COVID-19 patients.

\section{Compliance with ethical standards}

Conflict of interest The authors declare that they have no conflict of interest.

\section{References}

1. Wiersinga WJ, Rhodes A, Cheng AC, Peacock SJ, Prescott HC (2020) Pathophysiology, transmission, diagnosis, and treatment of coronavirus disease 2019 (COVID-19): A Review. Jama. 324:782

2. Worldmeter COVID-19 Coronavirus pandemic. https://www. worldometersinfo/coronavirus/. Accessed 5 Aug 2020

3. Statista number of tests for COVID-19 in most impacted countries worldwide as of Aug. 5, 2020. https://www.statistacom/statistics/ 1028731/covid19-tests-select-countries-worldwide/. Accessed 5 Aug 2020

4. Conticini E, Frediani B, Caro D (2020) Can atmospheric pollution be considered a co-factor in extremely high level of SARS-CoV-2 lethality in Northern Italy? Environ Pollut 261:114465

5. Fattorini D, Regoli F (2020) Role of the chronic air pollution levels in the Covid-19 outbreak risk in Italy. Environ Pollut 264:114732

6. Li H, Xu XL, Dai DW, Huang ZY, Ma Z, Guan YJ (2020) Air pollution and temperature are associated with increased COVID-19 incidence: a time series study. Int J Infect Dis 97:278-282

7. Vaduganathan M, Vardeny O, Michel T, McMurray JJV, Pfeffer MA, Solomon SD (2020) Renin-angiotensin-aldosterone system inhibitors in patients with Covid-19. N Engl J Med 382:1653-1659

8. Hoffmann M, Kleine-Weber H, Schroeder S, Kruger N, Herrler T, Erichsen S, Schiergens TS, Herrler G, Wu NH, Nitsche A et al (2020) SARS-CoV-2 cell entry depends on ACE2 and TMPRSS2 and is blocked by a clinically proven protease inhibitor. Cell 181: 271-280 e278

9. Muus C, Luecken MD, Eraslan G, Waghray A, Heinberg G, Sikkema L, Kobayashi Y, Vaishnav ED, Subramanian A, Smilie $\mathrm{C}$ et al Integrated analyses of single-cell atlases reveal age, gender, and smoking status associations with cell type-specific expression of mediators of SARS-CoV-2 viral entry and highlights inflammatory programs in putative target cells BioRxiv. https://doi.org/10. 1101/2020.04.19.049254

10. Ziegler CGK, Allon SJ, Nyquist SK, Mbano IM, Miao VN, Tzouanas CN, Cao Y, Yousif AS, Bals J, Hauser BM, Feldman J, Muus C, Wadsworth MH II, Kazer SW, Hughes TK, Doran B, Gatter GJ, Vukovic M, Taliaferro F, Mead BE, Guo Z, Wang JP, Gras D, Plaisant M, Ansari M, Angelidis I, Adler H, Sucre JMS, Taylor CJ, Lin B, Waghray A, Mitsialis V, Dwyer DF, Buchheit KM, Boyce JA, Barrett NA, Laidlaw TM, Carroll SL, Colonna L, Tkachev V, Peterson CW, Yu A, Zheng HB, Gideon HP, Winchell CG, Lin PL, Bingle CD, Snapper SB, Kropski JA, Theis FJ, Schiller HB, Zaragosi LE, Barbry P, Leslie A, Kiem HP, Flynn JAL, Fortune SM, Berger B, Finberg RW, Kean LS, Garber M, Schmidt AG, Lingwood D, Shalek AK, Ordovas-Montanes J, Banovich N, Barbry P, Brazma A, Desai T, Duong TE, Eickelberg O, Falk C, Farzan M, Glass I, Haniffa M, Horvath P, Hung D, Kaminski N, Krasnow M, Kropski JA,
Kuhnemund M, Lafyatis R, Lee H, Leroy S, Linnarson S, Lundeberg J, Meyer K, Misharin A, Nawijn M, Nikolic MZ, Ordovas-Montanes J, Pe'er D, Powell J, Quake S, Rajagopal J, Tata PR, Rawlins EL, Regev A, Reyfman PA, Rojas M, Rosen O, Saeb-Parsy K, Samakovlis C, Schiller H, Schultze JL, Seibold MA, Shalek AK, Shepherd D, Spence J, Spira A, Sun X, Teichmann S, Theis F, Tsankov A, van den Berge M, von Papen M, Whitsett J, Xavier R, Xu Y, Zaragosi LE, Zhang K (2020) SARS-CoV-2 receptor ACE2 is an interferon-stimulated gene in human airway epithelial cells and is detected in specific cell subsets across tissues. Cell 181:1016-1035 e1019

11. Mancia G, Rea F, Ludergnani M, Apolone G, Corrao G (2020) Renin-angiotensin-aldosterone system blockers and the risk of Covid-19. N Engl J Med 382:2431-2440

12. Reynolds HR, Adhikari S, Pulgarin C, Troxel AB, Iturrate E, Johnson SB, Hausvater A, Newman JD, Berger JS, Bangalore S, Katz SD, Fishman GI, Kunichoff D, Chen Y, Ogedegbe G, Hochman JS (2020) Renin-angiotensin-aldosterone system inhibitors and risk of Covid-19. N Engl J Med 382:2441-2448

13. Jarcho JA, Ingelfinger JR, Hamel MB, D'Agostino RB Sr, Harrington DP (2020) Inhibitors of the renin-angiotensinaldosterone system and Covid-19. N Engl J Med 382:2462-2464

14. Patel AB, Verma A (2020) COVID-19 and angiotensin-converting enzyme inhibitors and angiotensin receptor blockers: what is the evidence? Jama. https://doi.org/10.1001/jama.2020.4812

15. Fosbol EL, Butt JH, Ostergaard L, Andersson C, Selmer C, Kragholm K, Schou M, Phelps M, Gislason GH, Gerds TA et al (2020) Association of angiotensin-converting enzyme inhibitor or angiotensin receptor blocker use with COVID-19 diagnosis and mortality. Jama. 324:168-177

16. Crackower MA, Sarao R, Oudit GY, Yagil C, Kozieradzki I, Scanga SE, Oliveira-dos-Santos AJ, da Costa J, Zhang L, Pei Y et al (2002) Angiotensin-converting enzyme 2 is an essential regulator of heart function. Nature 417:822-828

17. Imai Y, Kuba K, Rao S, Huan Y, Guo F, Guan B, Yang P, Sarao R, Wada T, Leong-Poi H, Crackower MA, Fukamizu A, Hui CC, Hein L, Uhlig S, Slutsky AS, Jiang C, Penninger JM (2005) Angiotensinconverting enzyme 2 protects from severe acute lung failure. Nature 436:112-116

18. Monteil V, Kwon H, Prado P, Hagelkruys A, Wimmer RA, Stahl M, Leopoldi A, Garreta E, Hurtado Del Pozo C, Prosper F et al (2020) Inhibition of SARS-CoV-2 infections in engineered human tissues using clinical-grade soluble human ACE2. Cell 181:905913 e907

19. Chiu RW, Tang NL, Hui DS, Chung GT, Chim SS, Chan KC, Sung YM, Chan LY, Tong YK, Lee WS et al (2004) ACE2 gene polymorphisms do not affect outcome of severe acute respiratory syndrome. Clin Chem 50:1683-1686

20. Rigat B, Hubert C, Alhenc-Gelas F, Cambien F, Corvol P, Soubrier $\mathrm{F}$ (1990) An insertion/deletion polymorphism in the angiotensin Iconverting enzyme gene accounting for half the variance of serum enzyme levels. J Clin Invest 86:1343-1346

21. Riera-Fortuny C, Real JT, Chaves FJ, Morales-Suarez-Varela M, Martinez-Triguero ML, Morillas-Arino C, Hernandez-Mijares A (2005) The relation between obesity, abdominal fat deposit and the angiotensin-converting enzyme gene I/D polymorphism and its association with coronary heart disease. Int J Obes 29:78-84

22. He Q, Fan C, Yu M, Wallar G, Zhang ZF, Wang L, Zhang X, Hu R (2013) Associations of ACE gene insertion/deletion polymorphism, ACE activity, and ACE mRNA expression with hypertension in a Chinese population. PLoS One 8:e75870

23. Berge KE, Berg K (1997) Cardiovascular risk factors in people with different genotypes in the insertion/deletion (I/D) polymorphism at the locus for angiotensin I-converting enzyme (ACE). Clin Genet 52:422-426

24. Philipp CS, Dilley A, Saidi P, Evatt B, Austin H, Zawadsky J, Harwood D, Ellingsen D, Barnhart E, Phillips DJ et al (1998) 
Deletion polymorphism in the angiotensin-converting enzyme gene as a thrombophilic risk factor after hip arthroplasty. Thromb Haemost 80:869-873

25. Marshall RP, Webb S, Bellingan GJ, Montgomery HE, Chaudhari B, McAnulty RJ, Humphries SE, Hill MR, Laurent GJ (2002) Angiotensin converting enzyme insertion/deletion polymorphism is associated with susceptibility and outcome in acute respiratory distress syndrome. Am J Respir Crit Care Med 166:646-650

26. Delanghe JR, Speeckaert MM, De Buyzere ML (2020) The host's angiotensin-converting enzyme polymorphism may explain epidemiological findings in COVID-19 infections. Clin Chim Acta 505: 192-193

27. Poplawski A (1970) The effect o angiotensin II on the platelet aggregation induced by adenosine diphosphate, epinephrine and thrombin. Experientia 26:86

28. Grasselli G, Zangrillo A, Zanella A, Antonelli M, Cabrini L, Castelli A, Cereda D, Coluccello A, Foti G, Fumagalli R, Iotti G,
Latronico N, Lorini L, Merler S, Natalini G, Piatti A, Ranieri MV, Scandroglio AM, Storti E, Cecconi M, Pesenti A, for the COVID19 Lombardy ICU Network (2020) Baseline characteristics and outcomes of 1591 patients infected with SARS-CoV-2 admitted to ICUs of the Lombardy Region, Italy. Jama 323:1574-1581

29. Tsantes AE, Kopterides P, Bonovas S, Bagos P, Antonakos G, Nikolopoulos GK, Gialeraki A, Kapsimali V, Kyriakou E, Kokori S, Dima K, Armaganidis A, Tsangaris I (2013) Effect of angiotensin converting enzyme gene I/D polymorphism and its expression on clinical outcome in acute respiratory distress syndrome. Minerva Anestesiol 79:861-870

Publisher's note Springer Nature remains neutral with regard to jurisdictional claims in published maps and institutional affiliations. 